\title{
Selective predation by parrotfishes on the reef coral Porites astreoides
}

\author{
Randi D. Rotjan*, Sara M. Lewis \\ Department of Biology, Tufts University, Medford, Massachusetts 02155, USA
}

\begin{abstract}
Direct predation by parrotfishes (Scaridae) may be an important stressor and mortality agent for reef-building corals, yet the patterns and consequences of such predation have received little attention. In a Belizean back reef habitat, we found that parrotfish predation caused mortality of the common reef-building coral Porites astreoides with $>13 \%$ of $P$. astreoides colonies showing partial or total colony mortality. Predation was not uniformly distributed, as completely intact colonies occurred adjacent to heavily grazed colonies exhibiting $>50 \%$ tissue lost to parrotfish predation. We examined whether differential predation on $P$. astreoides colonies might reflect differences in either coral nutritional quality or in coral-associated macroborers. Nutritional quality of coral tissue, measured as C:N ratios, did not differ significantly between grazed and intact $P$. astreoides colonies. However, significantly higher densities of coral-associated macroborers (which included barnacles, polychaetes, and vermetid molluscs) were found in grazed portions compared to ungrazed portions of the same $P$. astreoides colony. Thus, one explanation for selective grazing on $P$. astreoides colonies is that parrotfishes may be targeting coral areas with higher densities of macroboring organisms. Comparison of $\mathrm{C}: \mathrm{N}$ ratios among possible dietary components suggests that macroborer consumption could potentially provide nutritional benefits to mainly herbivorous parrotfishes. These results corroborate a growing body of evidence to indicate that parrotfish predation is an important source of coral mortality, and provide a novel explanation for selective coral predation by parrotfishes.
\end{abstract}

KEY WORDS: Bioerosion · Coral reef conservation $\cdot$ Herbivory $\cdot$ Macroborers $\cdot$ Predation $\cdot$ Sparisoma Resale or republication not permitted without written consent of the publisher

\section{INTRODUCTION}

Scleractinian corals are the major architects of tropical reefs, providing the structural framework for a highly diverse assemblage of marine organisms. Because of their importance as ecosystem engineers (sensu Jones et al. 1994), considerable attention has been given to various natural and anthropogenic factors that impact coral fitness (reviewed by Hughes et al. 2003). Among natural factors, herbivorous fishes are typically considered critical to the maintenance of healthy coral reefs (Hughes 1994), as their grazing activities indirectly benefit corals through preventing overgrowth by competitively superior macroalgae (Birkeland 1977, Lewis 1986, McClanahan \& Muthiga 1998). Parrotfishes are important components of this herbivorous fish fauna, using their fused beak-like jaws to graze epilithic and endolithic algae from dead carbonate substrates. Yet some parrotfishes also consume live coral, and parrotfish grazing may play a more complex role in reef dynamics than has been appreciated previously.

In a study of feeding behavior and jaw morphology of 24 scarine parrotfish species on the Great Barrier Reef, Bellwood \& Choat (1990) found that corallivory was restricted to a few large, excavating species, including Bolbometopon muricatum, Chlorurus microrhinos, and Cetoscarus bicolor. Considerably less is known about parrotfish predation on Caribbean coral reefs, although there have been numerous anecdotal reports of parrotfish consuming live corals (Frydl 1979, Bythell et al. 1993, Bruggemann et al. 1994a,b, Bruckner \& Bruckner 1998, Bruckner et al. 2000). In spite of these observations, debate continues concerning the 
extent and importance of parrotfish corallivory on Altantic reefs (reviewed by Miller \& Hay 1998), reflecting a paucity of work that has systematically assessed the patterns and consequences of parrotfish predation for reef corals. Using coral transplants, previous studies have shown that susceptible coral species may be excluded from certain reef habitats by fish grazing activity (Neudecker 1979, Littler et al. 1989, GrottoliEverett \& Wellington 1997, Miller \& Hay 1998). Additional studies indicate that parrotfishes preferentially target certain coral species (Garzon-Ferreira \& ReyesNivia 2001), although the causes of such selectivity remain unknown. In addition, we still lack quantitative studies concerning the incidence, extent and consequences of parrotfish predation for a particular coral species.

The feeding habits of Indo-Pacific parrotfishes have been relatively well-studied (Bellwood \& Choat 1990), and corallivory has been found to be restricted to a few large excavating species that possess jaw stuctures capable of exerting large forces on the cutting edge. In the Caribbean, the most important coral grazing fish appears to be the stoplight parrotfish Sparisoma viride because of its large adult size. Numerous observations of adult $S$. viride feeding on live coral have been reported (Frydl 1979, Bythell et al. 1993, Bruggemann et al. 1994a,b, Bruckner \& Bruckner 1998, Miller \& Hay 1998, Bruckner et al. 2000, Sanchez et al. 2004). Parrotfishes produce distinctive grazing scars as they excavate portions of the skeleton along with live coral tissue; such scars consist of a series of parallel grooves caused by the crenulated edges of their fused teeth (Frydl 1979, Bellwood \& Choat 1990). Sparisoma viride adults allocate 1 to $1.3 \%$ of their bites to live corals in shallow reef zones in Bonaire, Netherlands Antilles (Bruggemann et al. 1994a,b). In previous work on the back reef habitat of Carrie Bow Cay, Belize, we observed that about $2 \%$ of all $S$. viride bites are taken on live Porites astreoides corals (S. Lewis unpubl. data), while no live coral consumption was observed for any other parrotfish.

To assess the causes and consequences of parrotfish predation on corals, this study was designed to address the following questions: (1) what is the incidence (\% of colonies grazed) and extent ( $\%$ tissue loss) of parrotfish predation on the common Caribbean coral, Porites astreoides; (2) is there differential predation by parrotfishes on particular $P$. astreoides colonies within a back reef habitat; (3) is selective parrotfish predation on $P$. astreoides explained by either differences in nutritional quality (measured as C:N) of coral tissue, or differences in abundance of coral-associated macroborers; (4) how do possible components of parrotfish diet compare in their nutritional quality $(\mathrm{C}: \mathrm{N})$ ? Coral reefs worldwide are in decline (Hallock et al. 1993, Knowl- ton 2001, Gardner et al. 2003), and answering these questions will provide insight into parrotfish predation as a potential source of chronic coral mortality.

\section{MATERIALS AND METHODS}

Study site. This study was conducted from July 2003 to February 2005 in a shallow ( 1 m depth) back reef habitat at Carrie Bow Cay, Belize $\left(16^{\circ} 48^{\prime} \mathrm{N}, 88^{\circ} 05^{\prime} \mathrm{W}\right)$ between the reef crest and a Thalassia-dominated reef flat (Ruetzler \& Macintyre 1982). Porites astreoides, a mound-forming coral, is the dominant coral species in this habitat. This habitat supports a high density of, and intense grazing by, herbivorous fishes, primarily species of Acanthurus, Sparisoma, and Scarus (Lewis \& Wainwright 1985, Lewis 1986). Adults and juveniles of several parrotfish species are common in this habitat, including Scarus croicensis, Scarus vetula, Sparisoma viride, Sparisoma chrysopterum, Sparisoma rubripinne, and Sparisoma aurofrenatum.

Coral mortality due to parrotfish predation. Because direct observations of parrotfishes consuming live coral are infrequent, we have followed Frydl (1979) and others (Littler et al. 1989, Miller \& Hay 1998) in using the presence of the distinctive grooved scars made by scarids grazing live coral (Fig. 1A) as an indicator of recent parrotfish grazing. Based on the above studies, the grazing scars we observed were most likely made by $S$. viride, but this assumption is not critical to our study.

To compare parrotfish grazing incidence on Porites astreoides across reef habitats, we surveyed live $P$. astreoides colonies for recent grazing damage across 6 reef habitats ranging from 1 to $18 \mathrm{~m}$ depth in February 2004. In each of these habitats, we surveyed all live $P$. astreoides colonies occurring within $5 \times 60 \mathrm{~m}^{2}$ belt transects, scoring each colony for presence or absence of recent parrotfish grazing scars.

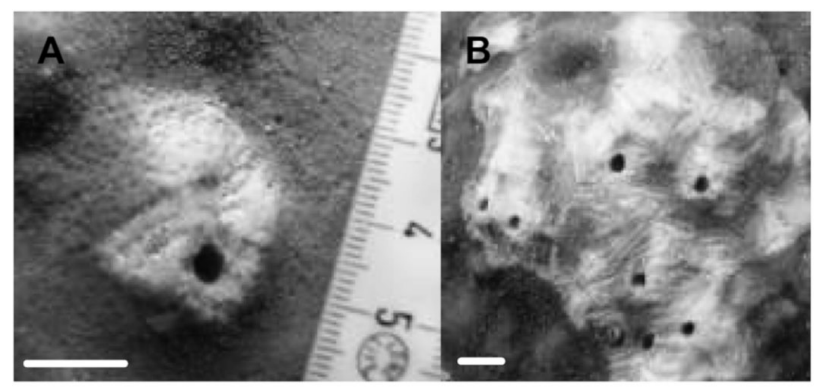

Fig. 1. Porites astreoides. (A) Characteristic parrotfish grazing scar with excavated hole formerly occupied by macroborer (either a serpulid polychaete, vermetid mollusk, or Ceratoconcha domingensis endolithic barnacle). Recent grazing scar shows distinctive parallel grooves formed by crenulated teeth on the cutting edge of parrotfish jaws. (B) Colony with parrotfish grazing scars (white area) surrounding macroborer holes. Scale bars $=1 \mathrm{~cm}$ 
To determine the incidence of parrotfish grazing (percentage of colonies grazed) on Porites astreoides within the back reef habitat, we censused all $P$. astreoides colonies within a $2044 \mathrm{~m}^{2}$ area $(\mathrm{n}=2769$ colonies). We scored each live colony for presence or absence of recent parrotfish grazing scars (defined as $\leq 1$ wk old, based on the absence of algal turf colonizing the grazed area). In addition, $P$. astreoides colonies showing complete coral tissue mortality were classified into 2 categories: mortality likely due to parrotfish predation (based on distinct parrotfish grazing scars over most of the colony surface, with no algal turf colonization), or mortality from unknown causes. This latter category included dead $P$. astreoides colonies that had been overgrown by algal turfs; although these colonies also showed parrotfish grazing scars, these were on dead coral substrate covered by algal turf.

We chose a subset of 31 recently grazed Porites astreoides colonies within the back reef habitat to measure grazing extent (percentage of live colony surface area removed by parrotfish grazing). This subset represented all of the recently grazed $P$. astreoides colonies present within a $250 \mathrm{~m}^{2}$ back reef area, and these colonies were individually marked to monitor changes over time. For each colony, we estimated the percentage (by quartile) of colony surface area lost to predation. We also photographed most of these recently grazed colonies $(n=27)$ to document initial damage in July 2003, and to monitor coral tissue regrowth 7 mo later.

Differences between grazed and intact Porites astreoides. To determine whether parrotfishes might preferentially graze areas of Porites astreoides with higher densities of macroboring organisms, we counted the number of surface-visible macroborers on grazed and intact $P$. astreoides. Compared to other scleractinians, $P$. astreoides shows relatively low susceptibility to boring organisms (Perry 1998), but this species does host the endolithic barnacle Ceratoconcha domingensis (Sterrer 1986), and tube-dwelling worms including both serpulid polychaetes (mostly Spirobranchus spp.) and vermetid mollusks (Dendropoma spp.). These long-lived macroborers are obligate associates of living coral; larvae settle on the colony surface and adults gradually extend their tubes as the coral grows outward (Smith 1984, Nishi \& Nishihira 1996). In this study, we assumed that each macroborer occupied a single tube and produced a single hole. Such a 1:1 ratio between macroborers and vacant holes was confirmed by removing small areas of live coral $(<1 \mathrm{~cm}$ depth, similar to indents resulting from parrotfish grazing) on $P$. astreoides colonies with and without surface-visible macroborers, and in all cases the areas without macroborers lacked holes. We focused on surface-visible macroborers for 2 reasons.
Firstly, these organisms are visible to parrotfishes, which are highly mobile, mainly visually-orienting consumers. Secondly, enumeration could be accomplished without collecting and sectioning coral colonies.

We used 2 methods to compare macroborer densities between grazed versus intact Porites astreoides colonies. (1) We compared grazed versus intact portions of the same colony; this paired design controlled for differences among colonies in other factors that could potentially affect either their susceptibility to macroborers (e.g. differences in skeletal density) or to grazing (e.g. differences in nutritional quality, nematocyst density, chemical defenses). We selected a subset of 39 partially grazed colonies (including the 31 colonies measured for grazing extent) from the back reef area, and for each colony measured grazed and intact surface area $\left(\mathrm{cm}^{2}\right)$ using a flexible ruler. Colonies ranged in size from approximately 250 to $2500 \mathrm{~cm}^{2}$. In intact portions of each colony, we counted the number of surface-visible macroborers. In grazed portions of each colony, we counted macroborers, using the holes they once occupied (Fig. 1). We compared macroborer density (combined endolithic barnacles and worms) in the intact versus grazed portion of each colony using a paired $t$-test. (2) We identified similarly sized grazed and intact $P$. astreoides colonies that were located within $1 \mathrm{~m}$ of each other (paired design, $\mathrm{n}=11$ pairs), and counted the number of surface-visible macroborers or holes (as above) on each colony; colony sizes were not measured for this comparison.

To determine if variation in nutritional quality (measured as C:N ratio) among Porites astreoides colonies might explain patterns of differential parrotfish predation, we conducted elemental analysis on coral tissue samples taken from 13 pairs of grazed and intact $P$. astreoides colonies in the back reef; grazed colonies were paired with nearby (within $1 \mathrm{~m}$ ) colonies of approximately equal size that showed no evidence of grazing. Coral nutritional quality could not be compared using a within-colony paired design because no live tissue remains in grazed portions of colonies. Approximately $4 \mathrm{~cm}^{2}$ of coral tissue was collected from each sample in July 2003 using a WaterPik Oral Irrigator with seawater and was dried at $60^{\circ} \mathrm{C}$ for elemental analysis as described below. We used a paired $t$-test to compare differences in nutritional quality between grazed versus intact $P$. astreoides tissue samples.

Nutritional quality of possible dietary components. We used C:N ratios to measure nutritional quality for several possible components of parrotfish diets, including algae, coral, and common macroborers of Porites astreoides. C:N ratios have traditionally been used as an indicator of nutritional quality (reviewed by Crossman et al. 2000, Purcell \& Bellwood 2001), although 
they only consider total (not dietary) carbon and nitrogen. We collected samples of Galaxaura subverticillata and Halimeda tuna (the most common macroalgal species in the back reef habitat) and algal turf, a diverse assemblage of filamentous algae that constitutes the majority of parrotfish diets (Lewis 1986). Large sand particles were removed from algal samples before drying, but no effort was made to remove any turf-associated detritus. Common macroborers were excavated from field-collected $P$. astreoides colonies: endolithic barnacles were dissected out of their valves and worms were removed from their tubes. These samples were dried at $60^{\circ} \mathrm{C}$ and transported to Boston for elemental analysis. All samples were analyzed with a NC-2500 Elemental Analyzer (CE Elantech) and run against an apple leaf standard. C:N ratios were compared among dietary components using a non-parametric KruskalWallis test followed by Dunn's multiple comparisons, as data were found to be heteroscedastic.

There has been some suggestion that coral-associated macroborers might increase the nitrogen content of host coral tissue. For example, nitrogen and phosphorus excreted by the barnacle Savignium milleporum is taken up by zooxanthellae in the hydrocoral Millepora dichotoma, and leads to increased coral growth rates (Cook et al. 1991, Achituv \& Mizrahi 1996). To investigate whether macroborers locally enhance nitrogen content of the surrounding Porites astreoides coral tissue, we compared the C:N ratios of coral tissue directly adjacent to macroborers of different types with coral tissue without macroborers. In January 2005, $P$. astreoides tissue samples were taken directly adjacent to each macroborer type (endolithic barnacles, serpulid polychaetes, vermetid mollusks; 10 samples of each macroborer type were taken, 1 from each of 10 colonies) and from 10 colonies without macroborers. These coral tissue samples were dried at $60^{\circ} \mathrm{C}$ for elemental analysis as described above. We first used ANOVA to examine differences in C:N between coral tissue sampled adjacent to 3 macroborer groups (endolithic barnacles, serpulid polychaetes, and vermetid mollusks). As these groups did not differ (ANOVA $F=1.643 ; \mathrm{df}=2,28 ; \mathrm{p}=0.211$ ), we pooled macroborers together and used a $t$-test to compare colonies with versus without macroborers.

\section{RESULTS}

\section{Coral mortality due to parrotfish predation}

A survey of parrotfish grazing incidence on live Porites astreoides colonies across reef habitats indicated that grazing incidence varied across habitats (Table 1), with no clear relationship with water depth.
Table 1. Porites astreoides. Parrotfish grazing incidence (\% of colonies recently grazed) across reef habitats $\left(5 \times 60 \mathrm{~m}^{2}\right.$ transects per habitat) at Carrie Bow Cay, Belize

\begin{tabular}{|lcc|}
\hline Depth $(\mathrm{m})$ & Reef habitat & $\begin{array}{c}\text { \% recently grazed } \\
\text { (no. colonies) }\end{array}$ \\
\hline 1 & Back reef & $2.1(364)$ \\
3 & Lagoon & $0(20)$ \\
5 & Upper spur and groove & $0.9(111)$ \\
10 & Lower spur and groove & $4.2(48)$ \\
15 & Outer ridge & $0(26)$ \\
18 & Inner reef slope & $2.2(46)$ \\
\hline
\end{tabular}

The highest grazing incidence on $P$. astreoides was found in the low spur and groove habitat (10 $\mathrm{m}$ depth), followed by the inner reef slope $(18 \mathrm{~m})$ and back reef $(1 \mathrm{~m})$ habitats. Parrotfish predation was not uniformly distributed; within the back reef habitat, the percentage of tissue removed from colonies by grazing varied widely (Fig. 2). Thirty-five percent of colonies had lost less than one-quarter of their live tissue $(\mathrm{n}=31$ colonies, minimum grazed area $=6.5 \mathrm{~cm}^{2}$ ), while $48 \%$ of colonies showed a loss of more than half their live tissue to recent parrotfish grazing.

In a more extensive survey conducted in the back reef habitat of all (live and dead) Porites astreoides ( $\mathrm{n}=$ 2769 colonies, Table 2), many colonies showed partial mortality due to parrotfish grazing (e.g. Fig. 3A), while more than $10 \%$ of colonies showed complete mortality due to parrotfish grazing (e.g. Fig. 3C). Of 27 recently grazed colonies that were photographically monitored, most showed little coral regrowth over parrotfish grazing scars after 7 mo. Five colonies showed some coral tissue regrowth along the margins of the grazing scar, while grazed areas in the remaining colonies were colonized by algal turf (Fig. 3B,D).

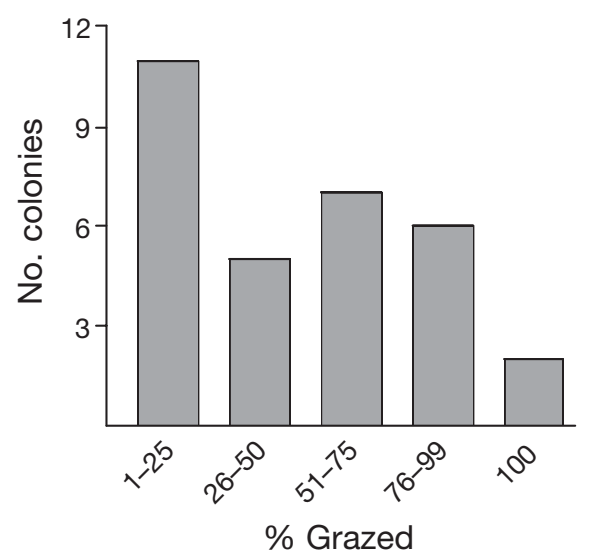

Fig. 2. Porites astreoides. Grazing extent (\% of coral tissue lost per colony) for recently grazed colonies in the back reef at Carrie Bow Cay, Belize ( $\mathrm{n}=31$ colonies) 
Table 2. Porites astreoides. Condition of corals over a $2044 \mathrm{~m}^{2}$ back reef area of Carrie Bow Cay, Belize $(n=2769$ colonies surveyed). Colony condition was scored as intact (no evidence of parrotfish grazing), grazed (either partial or complete mortality) or dead due to unknown causes (see 'Materials and methods')

\begin{tabular}{|lc|}
\hline Colony condition & \% colonies \\
& (no. colonies) \\
\hline Intact & $75.2(2082)$ \\
Grazed, partial mortality & $3.5(96)$ \\
Grazed, complete mortality & $10.2(282)$ \\
Complete mortality (unknown cause) & $11.1(309)$ \\
\hline
\end{tabular}

\section{Macroborer density and nutritional quality of grazed versus intact corals}

Significantly greater macroborer density was found in grazed compared to intact portions of the same Porites astreoides colonies (Fig. 4A; mean difference $\pm \mathrm{SE}=$ $0.018 \pm 0.006$ macroborers $\mathrm{cm}^{-2}$, paired $t$-test $=2.864, \mathrm{n}=$ $39, p=0.007$ ), indicating increased likelihood of parrotfish grazing in areas with higher macroborer density within a colony. For between-colony comparisons (not adjusted for colony size), more macroborers were also observed in grazed $P$. astreiodes colonies (Fig. 4B), although this difference was not significant (mean difference $\pm \mathrm{SD}=0.818 \pm 4.976$ macroborers colony ${ }^{-1}$, paired $t$-test $=0.545, \mathrm{n}=11, \mathrm{p}=0.597$ ). Porites astreoides coral tissue nutritional quality, measured as $\mathrm{C}: \mathrm{N}$, was not significantly different between adjacent grazed and intact colonies (Fig. 5; mean difference \pm SE $=0.016 \pm$ 0.271 , paired $t$-test $=0.060, \mathrm{n}=13, \mathrm{p}=0.953$ ). In addition, $P$. astreoides coral tissue taken directly adjacent to macroborers exhibited $\mathrm{C}: \mathrm{N}$ ratios that did not differ significantly compared to coral tissue from colonies without macroborers (with macroborers: mean $\pm 1 \mathrm{SE}=$ $9.596 \pm 0.171, \mathrm{n}=30$; without macroborers: mean \pm $1 \mathrm{SE}=9.787 \pm 0.309, \mathrm{n}=10 ; t$-test, $\mathrm{t}=0.549, \mathrm{p}=0.586)$.

\section{Nutritional quality of possible dietary components}

Overall, C:N ratios differed significantly among several possible components of parrotfish diets, including Porites astreoides colonies, macroborers, and algae (Fig. 6; Kruskal-Wallis $=43.236, \mathrm{df}=7, \mathrm{p}<0.0001$ ) . Macroboring serpulids, vermetids, and barnacles had similarly low C:N ratios (Dunn's multiple comparisons, all $\mathrm{p}>0.50$ ), with serpulids possessing significantly lower C:N ratios (higher nitrogen content) when compared to both grazed and intact $P$. astreoides (Dunn's multiple comparisons, both $0.02<\mathrm{p}<0.05$ ). Serpulids and vermetids had significantly lower $\mathrm{C}: \mathrm{N}$ ratios compared to any algal types examined (Dunn's multiple comparisons, all $\mathrm{p}<0.01$ ). Barnacles did not differ from any of the other food types (all $\mathrm{p}>0.10$ ), likely due to highly variable $\mathrm{C}: \mathrm{N}$ ratios.
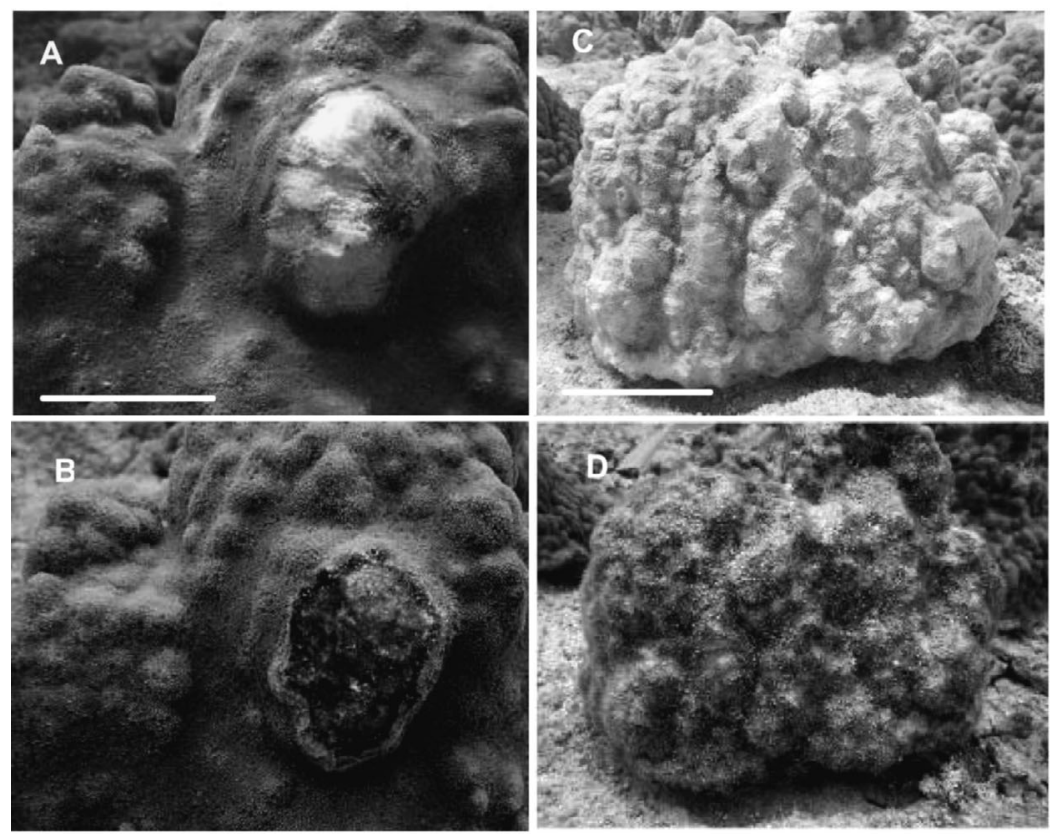

Fig. 3. Porites astreoides. (A) Partially grazed colony with recent parrotfish grazing marks surrounded by live coral tissue. Scale bar $=5 \mathrm{~cm}$. (B) Same colony after 7 mo with no coral regeneration. (C) Total mortality of a colony due to parrotfish grazing. Scale bar $=10 \mathrm{~cm}$. (D) Same colony after 7 mo covered by turf algae with no coral regeneration

\section{DISCUSSION}

Although there have been numerous anecdotal reports of coral predation by parrotfishes (Darwin 1842, Frydl \& Stearn 1978, Frydl 1979), surprisingly few studies have examined the patterns or the consequences of parrotfish predation on reef corals. While Indo-Pacific coral reefs support a more diverse corallivorous fish fauna (Hixon 1997), this functional group is dominated by parrotfishes in the tropical western Atlantic. The present study has made several new contributions to our understanding of parrotfish corallivory in coral reef communities. Our results demonstrated that parrotfish predation has a direct adverse effect on coral survival, based on the incidence and extent of parrotfish predation on the common Caribbean coral Porites astreoides. In a Belizean back reef habitat, more than $13 \%$ of $P$. astreoides colonies showed 

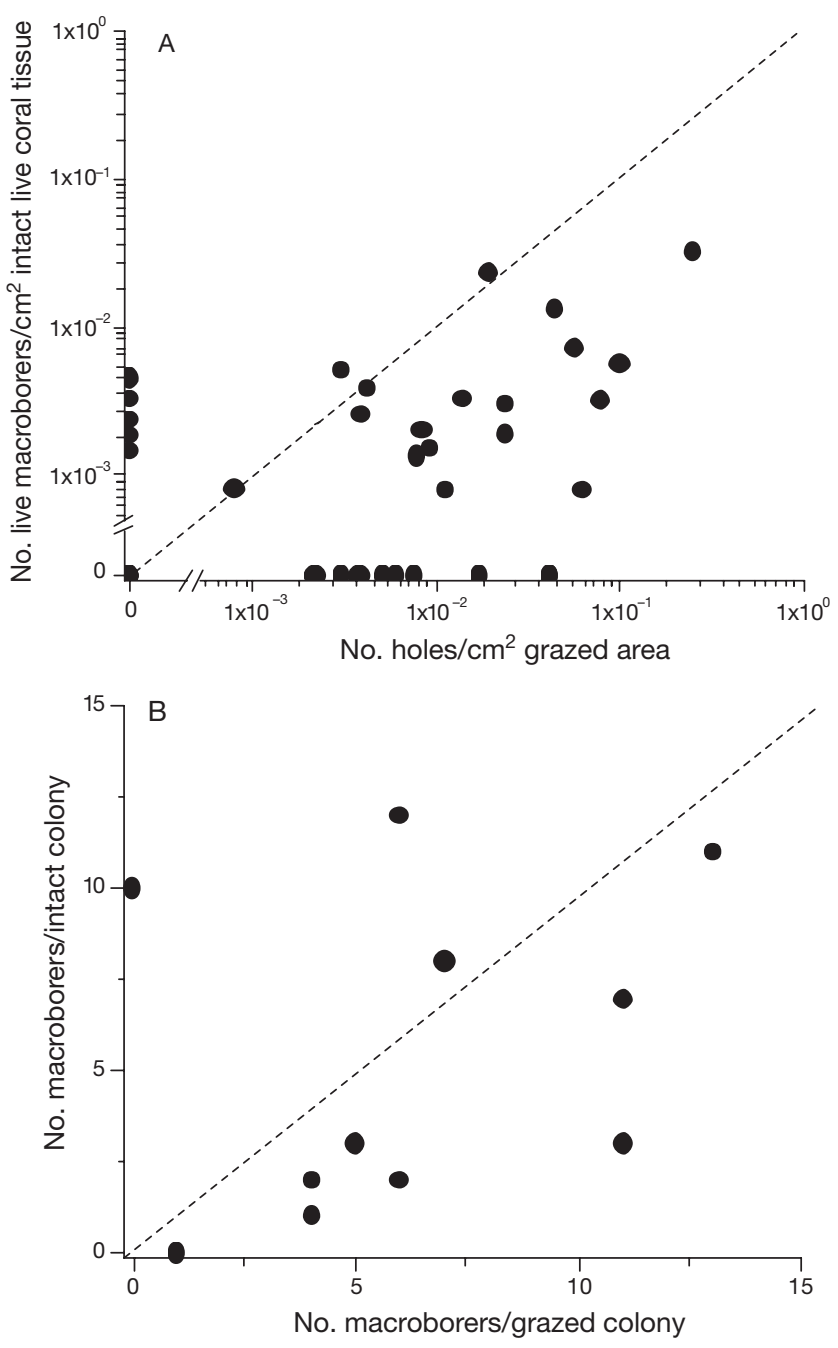

Fig. 4. Porites astreoides. Paired comparisons of macroborers on grazed and intact corals. Dashed lines indicate null hypothesis of equal density or abundance. (A) Density of macroborers (total number of serpulid polychaetes, vermetid mollusks, and endolithic barnacles) per unit area of intact colony compared to the total number of holes formerly occupied by macroborers in recently grazed areas ( $\mathrm{n}=39$ colonies). Axes breaks indicate transitions from linear to log scales. (B) Comparison of macroborer abundance between similarly sized grazed versus intact colonies located within $1 \mathrm{~m}$ of each other; $\mathrm{n}=11$ paired colonies

partial or complete mortality due to parrotfish grazing, with little coral recovery after $7 \mathrm{mo}$. The absence of coral recovery following parrotfish grazing is consistent with previous studies that found minimal tissue regeneration of artificial lesions on P. astreoides (Bak \& Steward-Van Es 1980). Our present research indicated that parrotfish predation may represent a chronic source of mortality for some Caribbean reef corals.

We also demonstrated that parrotfishes prey selectively on particular colonies within a coral species:

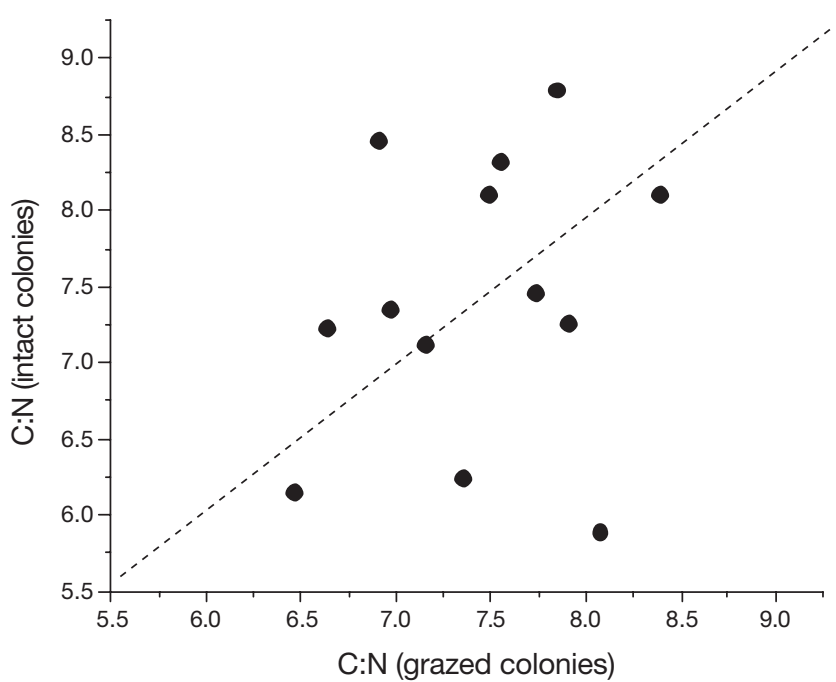

Fig. 5. Porites astreoides. Paired comparison of C:N ratios for coral tissue taken from grazed versus intact colonies. Dashed line indicates null hypothesis of equal $\mathrm{C}: \mathrm{N}$ for grazed and intact colonies; $\mathrm{n}=13$ pairs of colonies located within $1 \mathrm{~m}$ of each other

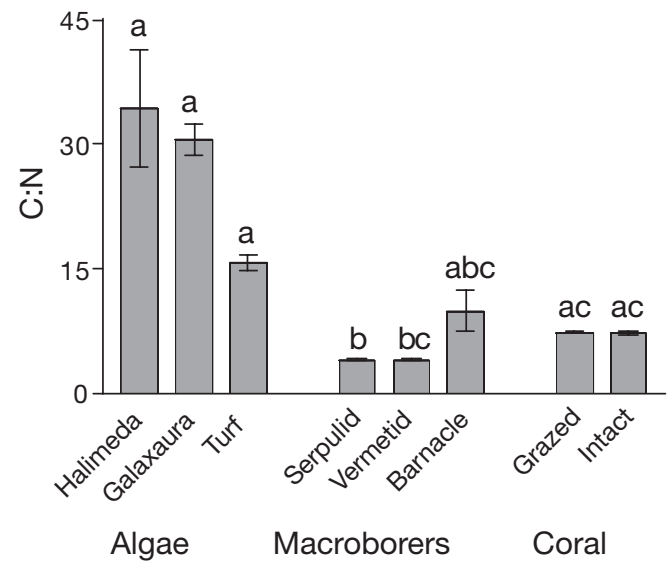

Fig. 6. Nutritional quality (measured as C:N ratio) of possible components of parrotfish diets. Algae: back reef algal species Galaxaura spp. $(\mathrm{n}=3)$, Halimeda $(\mathrm{n}=3)$, and turf algae $(n=5)$; macroborers: serpulid polychaetes $(n=9)$, vermetid mollusks $(\mathrm{n}=4)$ and endolithic barnacles Ceratoconcha domingensis $(\mathrm{n}=8)$; and Porites astreoides coral: intact $(\mathrm{n}=$ $13)$ and grazed $(n=13)$ colonies. Bars are mean $\pm S E$; letters designate homogenous subgroups from Dunn's multiple comparisons tests

within a single habitat some Porites astreoides colonies are heavily grazed while others remain intact (Fig. 2, Table 2). Previous studies have shown selective feeding on particular coral species by butterflyfishes (Neudecker 1979), pufferfishes (Grotolli-Everett \& Wellington 1997), and parrotfishes (Littler et al. 1989, Miller \& Hay 1998, Garzon-Ferreira \& Reyes-Nivia 2001). Taken together, these studies indicate that fish predation can be an important source of coral mortality 
in many geographic regions. Our results support a novel explanation for selective corallivory within a given coral species. We found that parrotfishes selectively targeted particular areas of $P$. astreoides colonies with higher densities of macroboring organisms (Fig. 4). In contrast, we found no support for the hypothesis that parrotfishes selectively graze $P$. astreoides colonies with higher nutritional quality (Fig. 5). We also found no evidence that macroborers enrich the nitrogen content of surrounding coral tissue, which suggests that parrotfishes may be attracted to the macroborers themselves rather than to the surrounding coral tissue. Considerable previous work has established that boring organisms are major contributors to the bioerosion of carbonate substrates in coral reef ecosystems (Highsmith et al. 1983, Hutchings 1986, Macdonald \& Perry 2003). Our work suggests that boring organisms may place reef corals in double jeopardy, not only by eroding coral skeletons but also by attracting parrotfish grazers. Although it is as yet undetermined whether macroborer presence increases fish predation on other coral species, a similar phenomenon of coral predators targeting areas of high macroborer density has been noted in Moorea for the Indo-Pacific coral Porites lobata (P. Edmunds pers. comm.).

Our findings suggest that parrotfishes may target coral areas with high macroborer density for the nutritional benefits directly provided by the associated macrofauna. Parrotfishes have generally been classified as herbivores (Randall 1967, Horn 1989, Choat 1991), which are likely to be nitrogen-limited (Mattson Jr 1980, Choat 1991, Bruggemann et al. 1994b,c, Choat \& Clements 1998). However, recent work on IndoPacific parrotfishes suggests that certain herbivorous species might be more accurately classified as detritivores (Crossman et al. 2001, Choat et al. 2002,2004, Wilson et al. 2003). It has also been suggested that consumption of detritus and associated microbes may provide considerable amounts of nitrogen to IndoPacific parrotfish diets (Choat \& Clements 1998, Crossman et al. 2001, Wilson et al. 2003). Although the relative importance of detritus to Caribbean parrotfish diets has not yet been examined, there is evidence that nitrogen content can affect parrotfish food choice. Recent work has shown that the Caribbean seagrass parrotfish Sparisoma radians selectively targets nitrogen-enriched Thalassia testudinum blades (Goecker et al. 2005). In our study, serpulid polychaetes were the only macroborer containing significantly more nitrogen than coral tissue or algae (Fig. 6); nevertheless, these results suggest that macroborers could be a potentially valuable food source for Caribbean parrotfishes. A major limitation of the present study is that we did not directly observe macroborer consumption by parrotfishes, which could be addressed using remote videography in future studies.

An alternate explanation that has been proposed for selective coral grazing by Sparisoma viride is that terminal-phase males may graze particular corals in order to mark their breeding territories (Bruggemann et al. 1994b, van Rooij et al. 1995). However, the present study does not support this explanation for selective corallivory on Porites astreoides. The shallow back reef habitat of Carrie Bow Cay supports large foraging schools of mainly initial phase adult $S$. viride (Lewis \& Wainwright 1985, Lewis 1986). Even though this is not a breeding habitat for $S$. viride, some $P$. astreoides colonies were extensively grazed by parrotfishes. Furthermore, low grazing incidence on $P$. astreoides was found in reef habitat such as the outer ridge, where high reproductive activity would be expected. Thus, while we cannot rule out territory marking as an explanation for selective parrotfish corallivory in some situations, our findings are not consistent with this explanation.

Other potential explanations for selective grazing by parrotfishes include differences in coral skeletal density (Littler et al. 1989, Bruggemann et al. 1996), as well as other morphological and chemical coral defenses. However, among several Caribbean corals, no correlation is apparent between live coral skeletal density (Highsmith 1981) and parrotfish grazing incidence (Littler et al. 1989, Garzon-Ferreira \& Reyes-Nivia 2001). Additionally, since Porites astreoides skeletal density shows little intraspecific variation (Highsmith 1981), it is unlikely to account for the selective grazing both among and within colonies as demonstrated. Some corallivorous fishes may be deterred by other coral defenses. For example Chaetodon multicinctus, an Indo-Pacific butterflyfish, has been shown to discriminate among $P$. compressa colonies based on differences in defensive nematocyst density (Gochfeld 2004). However, parrotfishes may not be easily deterred by nematocyst defenses, based on anectodal accounts of Sparisoma viride grazing on Millepora fire corals (Frydl 1979). As suggested by Miller \& Hay (1998) and Harvell (1999), interspecific or intraspecific differences in coral chemical defenses against predators may also contribute to parrotfish feeding selectivity.

Coral reefs are highly diverse communities with complex trophic interactions, and at least some parrotfishes appear to play multifaceted roles in reef dynamics (Miller \& Hay 1998). When parrotfishes forage on seaweeds, they provide an indirect benefit to corals, increasing coral survivorship and recruitment by removing competitively superior algae (reviewed by Hixon 1997). Conversely, our research demonstrated that parrotfish predation could have direct detrimental 
effects on reef-building coral species. Because of their large size, high mobility, and powerful beak-like dentition (Bellwood \& Choat 1990), excavating parrotfishes have the potential to exert major effects on coral reef community structure. Additional studies are needed to examine if and how patterns and consequences of parrotfish corallivory vary across habitats and among geographic regions.

Acknowledgements. We thank M. Carpenter and J. \& S. Alanko for logistical support and K. Ruetzler for his encouragement, as well as J. Dimond and D. Kemp for their help in the field. We thank P. Wainwright, C. Kicklighter, M. Goecker, and P. Edmunds for useful discussions, and R. Ruess, O. Ambrogio, K. Demary, T. Fedina and 3 anonymous reviewers whose helpful comments improved this manuscript. This research was funded by the Smithsonian Caribbean Coral Reef Ecosystems Program (CCRE contribution \#680) and the Tufts University Institute of the Environment.

\section{LITERATURE CITED}

Achituv Y, Mizrahi L (1996) Recycling of ammonium within a hydrocoral (Millepora dichotoma)-zooxanthellaecirripede (Savignium milleporum) symbiotic association. Bull Mar Sci 58:856-860

Bak RPM, Steward-Van Es Y (1980) Regeneration of superficial damage in the scleractinian corals Agaricia agaricites f. purpurea and Porites astreoides. Bull Mar Sci 30: 883-887

Bellwood DR, Choat JH (1990) A functional analysis of grazing in parrotfishes (family Scaridae): the ecological implications. Environ Biol Fish 28:189-214

Birkeland CE (1977) The importance of rate of biomass accumulation in early successional stages of benthic communities to the survival of coral recruits. Proc 3rd Int Coral Reef Symp, Miami 1:15-21

Bruckner AW, Bruckner RJ (1998) Destruction of coral by Sparisoma viride. Coral Reefs 17:350

Bruckner AW, Bruckner RJ, Sollins P (2000) Parrotfish predation on live coral: 'spot biting' and 'focused biting'. Coral Reefs 19:50

Bruggemann JH, Kuyper MWM, Breeman AM (1994a) Comparative analysis of foraging and habitat use by the sympatric Caribbean parrotfish Scarus vetula and Sparisoma viride (Scaridae). Mar Ecol Prog Ser 112:51-66

Bruggemann JH, van Oppen MJH, Breeman AM (1994b) Foraging by the stoplight parrotfish Sparisoma viride. I. Food selection in different, socially determined habitats. Mar Ecol Prog Ser 106:41-55

Bruggemann JH, Begeman J, Bosma EM, Verburg P, Breeman AM (1994c) Foraging by the stoplight parrotfish Sparisoma viride. II. Intake and assimilation of food, protein, and energy. Mar Ecol Prog Ser 106:57-71

Bruggemann JH, van Kessel AM, van Rooij JM, Breeman AM (1996) Bioerosion and sediment ingestion by the Caribbean parrotfish Scarus vetula and Sparisoma viride: implications of fish size, feeding mode, and habitat use. Mar Ecol Prog Ser 134:59-71

Bythell J, Bythell M, Gladfelter E (1993) Initial results of a long-term coral reef monitoring program: Impact of Hurricane Hugo at Buck Island Reef National Monument, St. Croix, U.S. Virgin Islands. J Exp Mar Biol Ecol 172: 171-183
Choat JH (1991) The biology of herbivorous fishes on coral reefs. In: Sale PF (ed) The ecology of coral reef fishes. Academic Press, New York p 120-155

Choat JH, Clements KD (1998) Vertebrate herbivores in marine and terrestrial environments: a nutritional ecology perspective. Annu Rev Ecol Syst 29:375-403

Choat JH, Clements KD, Robbins WD (2002) The trophic status of herbivorous fishes on coral reefs I. Dietary analyses. Mar Biol 140:613-623

Choat JH, Robbins WD, Clements KD (2004) The trophic status of herbivorous fishes on coral reefs 2 . Food processing modes and trophodynamics. Mar Biol 145:445-454

Cook PA, Stewart BA, Achituv Y (1991) The symbiotic relationship between the hydrocoral Millepora dichotoma and the barnacle Savignium milleporum. J Appl Meteor $32: 285-290$

Crossman DJ, Clements KD, Cooper GJS (2000) Determination of protein for studies of marine herbivory: a comparison of methods. J Exp Mar Biol Ecol 244:45-65

Crossman DJ, Choat JH, Clements KD, Hardy T, McConochie $\mathrm{J}$ (2001) Detritus as food for grazing fishes on coral reefs. Limnol Oceanogr 46:1596-1605

Darwin CR (1842) The structure and distribution of coral reefs. Smith, Elder \& Co, London

Frydl P (1979) The effect of parrotfish (Scaridae) on coral in Barbados, W.I. Int Revue Gesamt Hydrobiol 64:737-748

Frydl P, Stearn CW (1978) Rate of bioerosion by parrotfish in Barbados reef environments. J Sediment Petrol 48: 1149-1158

Gardner TA, Cote IM, Gill JA, Grant A, Watkinson AR (2003) Long-term region-wide declines in Caribbean corals. Science 301:958-960

Garzon-Ferreira J, Reyes-Nivia MC (2001) Incidence of fish predation on stony corals at four atolls of the archipelago of San Andres and Providencia (Colombian Caribbean). Bol Invest Mar Cost 30:133-150

Gochfeld D (2004) Predation-induced morphological and behavioral defenses in a hard coral: implications for foraging behavior of coral-feeding butterflyfishes. Mar Ecol Prog Ser 267:145-158

Goecker ME, Heck Jr KL, Valentine JF (2005) Effects of nitrogen concentrations in turtlegrass Thalassia testudinum on consumption by the bucktooth parrotfish Sparisoma radians. Mar Ecol Prog Ser 286:239-248

Grottoli-Everett AG, Wellington GM (1997) Fish predation on the scleractinian coral Madracis mirabilis controls its depth distribution in the Florida Keys, USA. Mar Ecol Prog Ser 160:291-293

Hallock P, Muller-Harger FE, Hallas JC (1993) Coral reef decline. Natl Geogr Res Explor 9:358-378

Harvell CD (1999) Complex biotic environments, coloniality, and heritable variation for inducible defenses. In: Harvell CD (ed) The ecology and evolution of inducible defenses. Princeton University Press, Princeton NJ, p 231-244

Highsmith RC (1981) Coral bioerosion: damage relative to skeletal density. Am Nat 117:193-198

Highsmith RC, Lueptow RL, Schonberg SC (1983) Growth and bioerosion of three massive corals on the Belize barrier reef. Mar Ecol Prog Ser 13:261-271

Hixon MA (1997) Effects of reef fishes on corals and algae. In: Birkeland C (ed) Life and death of coral reefs. Chapman \& Hall, New York p 230-248

Horn MH (1989) Biology of marine herbivorous fishes. Oceanogr Mar Biol Annu Rev 27:161-272

Hughes TP (1994) Catastrophes, phase shifts, and large scale degradation of a Caribbean coral reef. Science 256: $1574-1551$ 
Hughes TP, Baird AH, Bellwood DR, Card M and 13 others (2003) Climate change, human impacts, and the resilience of coral reefs. Science 301:929-933

Hutchings PA (1986) Biological destruction of coral reefs: a review. Coral Reefs 4:239-252

Jones CG, Lawton JH, Shachak M (1994) Organisms as ecosystem engineers. Oikos 69:373-386

Knowlton N (2001) The future of coral reefs. PNAS 98: 5419-5425

Lewis SM (1986) The role of herbivorous fishes in the organization of a Caribbean reef community. Ecol Monogr 56: $183-200$

Lewis SM, Wainwright PC (1985) Herbivore abundance and grazing intensity on a Caribbean coral reef. J Exp Mar Biol Ecol 87:215-228

Littler MM, Taylor PR, Littler DS (1989) Complex interactions in the control of coral zonation on a Caribbean reef flat. Oecologia 80:331-340

Macdonald IA, Perry CT (2003) Biological degradation of coral framework in a turbid lagoon environment, Discovery Bay, north Jamaica. Coral Reefs 22:523-535

Mattson Jr WJ (1980) Herbivory in relation to plant nitrogen content. Annu Rev Ecol Syst 11:119-161

McClanahan TR, Muthiga NA (1998) Changes in Kenyan coral reef community structure and function due to exploitation. Hydrobiologia 166:269-276

Miller MW, Hay ME (1998) Effects of fish predation and seaweed competition on the survival and growth of corals. Oecologia 113:231-238

Neudecker S (1979) Effects of grazing and browsing fishes on the zonation of corals in Guam. Ecology 60:666-672

Nishi E, Nishihira M (1996) Age-estimation of the christmas

Editorial responsibility: Charles Birkeland (Contributing

Editor), Honolulu, Hawaii, USA tree worm Spirobranchus giganteus (Polychaeta, Serpulidae) living buried in the coral skeleton from the coralgrowth band of the host coral. Fish Sci 62:400-403

Perry CT (1998) Macroborers within coral framework at Discovery Bay, north Jamaica: species distribution and abundance, and effects on coral preservation. Coral Reefs 17: $277-287$

Purcell SW, Bellwood DR (2001) Spatial patterns of epilithic algal and detrital resources on a windward coral reef. Coral Reefs 20:117-125

Randall JE (1967) Food habits of reef fishes of the West Indies. Proc Int Conf Trop Oceanogr, Miami 5:665-847

Ruetzler K, MacIntyre IG (eds) (1982) The Atlantic barrier reef ecosystem at Carrie Bow Cay, Belize, I: Structure and communities. Smithsonian Contributions to the Marine Sciences 12, Smithsonian Institution Press, Washington, DC

Sanchez JA, Gil MF, Chasqui LH, Alvarado EM (2004) Grazing dynamics on a Caribbean reef-building coral. Coral Reefs 23:578-583

Smith R (1984) Development and settling of Spirobranchus giganteus (Polychaeta; Serpulidae). Proc 1st Int Polychaete Conf, Sydney, p 147-153

Sterrer W (1986) Marine fauna and flora of Bermuda: a systematic guide to the identification of marine organisms. Wiley Interscience, New York

van Rooij JM, Bruggemann JH, Videler JJ, Breeman AM (1995) Ontogenetic, social, spatial and seasonal variations in condition of the reef herbivore Sparisoma viride. Mar Biol 123:269-275

Wilson SK, Bellwood DR, Choat JH, Furnas MJ (2003) Detritus in the epilithic algal matrix and its use by coral reef fishes. Oceanogr Mar Biol Annu Rev 41:279-309

Submitted: May 2, 2005; Accepted: July 21, 2005

Proofs received from author(s): November 30, 2005 